\title{
God Does Not Prefer Sons Over Daughters (!)
}

\section{Qur'anic Verses on Gender Equality}

It feels odd even having to deny this bizarre idea, but since apparently those who make this argument often reference certain Qur'anic verses taken out of context, ${ }^{1}$ the idea warrants addressing.

- Yes, there are at least seven instances ${ }^{2}$ in which the Qur'an denounces the idea of God having daughters. But this is in the context of criticising the pagan Meccans' worship of female deities whom they claimed were God's daughters, and also in response to certain tribes' belief that the angels were God's daughters.

These ideas are denounced outright in the Qur'an, which proceeds in several instances to also point out the idolaters' insolence in moreover ascribing to God what they deemed to be an undesirable gender to have as their own offspring. Such was the pagan Arabs' dislike of having daughters that they had a custom of burying alive unwelcome female babies, a practice vehemently condemned in the Qur'an repeatedly.

${ }^{1}$ Lang, Jeffrey. 1995. Struggling to Surrender: Some Impressions from an American Convert to Islam. Maryland: Amana Publications, 146-49.

${ }^{2}$ Verses denouncing the claim that God has daughters include 4:117, 16:57-59, 17:40, 37:149-53, 43:16, 52:39, 53:19-21. Overall, the Qur'an denounces the idea of God having children at all, insisting that angels and prophets and regular human beings are all essentially God's subjects, i.e. they are His creation, not offspring.

(C) The Author(s) 2022

L. El-Ali, No Truth Without Beauty, Sustainable Development

Goals Series, https://doi.org/10.1007/978-3-030-83582-8_10 
Here is an example of this combination of rebukes:

The Bees, 16:57-59

And they assign to God daughters-glory be to Him!-while to themselves what they

desire.

And when one of them receives news of a female child, his face darkens, and he chokes

inwardly.

He hides from people on account of the bad news he has received: should he keep it in humiliation, or bury it in the dust? How evil is their judgment!

- Yes, the Qur'an does say at one point that “...the male is not like the female...". But the context reveals it to be a factual statement relating to the Virgin Mary's birth-Mary, no less!-in a discourse involving Mary's mother Hannah, wife of Joaquim: ${ }^{3}$

The House of 'Imrān (Joaquim, father of Mary), 3:35-37

Remember when the wife of 'Imrān said: My Lord, I dedicate what is in my belly to you as a consecrated offering. So accept it from me. Truly you are the All-Hearing, the All-Knowing.

Then when she delivered her, she said: My Lord, I have delivered a female. And God knew well what she had delivered-the male is not like the female. And I have named her Mary, and I seek refuge in You for her and her progeny from Satan, the outcast.

And her Lord accepted her with a beautiful acceptance, and made her grow in a beautiful way, and entrusted Zacharia with her...

Ironically, if we were to set context aside altogether and look at the phrase "...the male is not like the female..." through a purely linguistic lens, we would have a stronger case for arguing that this verse is saying that the female is the superior being!

Anyway, the critical point here is this: When “...the male is not like the female..." is cited out of its natural context shown above, it is bound to

${ }^{3}$ See commentary on 3:35-36 in Nasr, Seyyed Hossein (editor-in-chief) et al. 2015. The Study Quran: A New Translation and Commentary. New York: HarperCollins Publishers, 141. 
sound like a judgmental statement regarding the two sexes, one way or another. It is then also easy to miss the fact that though Hannah dedicated her unborn child to God before knowing its gender (while praying for a boy) ${ }^{4}$ God as Creator decided to make that child a givl and proceeded to not only accept her as an offering but to elevate her above all women (3:42) as well as above all men barring God's prophets, among whom Mary is listed as an equal in her own right and not only as the mother of Jesus. This occurs in a long flow of verses in the chapter in fact entitled "The Prophets", verses 21:48-92, which essentially tell us the following:

- That God gave Moses and Aaron the Criterion (of right and wrong), and a light and a reminder to the reverent

- And He gave Abraham his sound judgment (the Qur'an retells Abraham's story here at length, showing his courageous steadfastness in the face of the idolaters)

- And God additionally bestowed upon Abraham Isaac (his son) and Jacob (his grandson), and made them leaders (imams) in God's way

- And Lot was given judgment and knowledge, and was saved from the morally corrupt town

- And Noah's prayer was answered and he was saved, alongside his family

- And God gave David and Solomon sound judgment and knowledge, and gave Solomon the power to command the wind towards the blessed land

- And Job's prayer was answered and his affliction was lifted, and he was given his family and others like them in mercy and as a reminder to others

- And Ishmael, Idriss (either Enoch or Elias) and Dhul-Kifl (a prophet of disputed identity $)^{5}$ were all made to enter into God's mercy

- And he of the whale (Jonah), whose prayer was answered, was thus saved from grief

- And Zacharia had prayed for a child and so God healed his barren wife and bestowed John upon him

- "And she who preserved her chastity [Mary] and We breathed into her of Our Spirit, and made her and her son [Jesus] a sign for all the worlds" (21:91)

and finally, in exquisite conclusion to this particular listing of some of the prophets sent by God to humanity:

${ }^{4}$ Ibid.

${ }^{5}$ Ibid., 824. 
- "This is your (pl.) community (umma) — a single community—and I am your Lord, so worship Me.” (21:92)

In fact, such are the patriarchal influences on the interpretation of the Qur'an that they have even crept into Western Arabists' translation of the Qur'an in a number of ways. In one example, the word "children" is rendered "sons" in all but a couple of translations I have seen of the following verse, which was already cited earlier:

\section{The Bees, 16:72}

And God made for you (pl.) mates from your own souls, and made for you from your mates children [i.e. not just sons] and grandchildren, and provided you with good things.....

Meanwhile, other verses that speak of the two genders at the same time are completely ignored-notice how the order is reversed in the two mentions of gender here, almost as if to emphasise their interchangeability, or sameness:

\section{Consultation, 42:49-50}

And to God belong the heavens and the earth. He creates what $\mathrm{He}$ wills. $\mathrm{He}$ bestows upon whom $\mathrm{He}$ wills females, and $\mathrm{He}$ bestows upon whom $\mathrm{He}$ wills males.

Or He pairs them, male and female, and makes whom He wills barren. For He is all-Knowing, all-Powerful.

In summary, the two phrases sometimes plucked out of either their full verse or their accompanying verses to be cited as supposed proof that the male is superior to the female are:

and they assign to God daughters—glory be to Him!... (16:57)

and

...the male is not like the female... (3:36)

when in fact these two phrases are about something totally different:

Verse 16:57 is about the absurdity of the pagan worship of their female deities and the insolence of their assigning to God daughters when they considered baby girls to not be good enough for themselves, going so far as to bury them alive at times. 
Verse 3:36 is about the birth of Mary even though her mother had prayed for a son to dedicate to God, and God's full acceptance of the offered daughter and His making of Mary and her son, Jesus, a sign for all the worlds.

This is straight from the Qur'an, and that truly is all we need. But I cannot resist asking, nonetheless, why if God truly favoured boys over girls, $\mathrm{He}$ would have allowed His beloved prophet Muhammad to enjoy only daughters — four in total—while letting his three sons die in infancy.

\section{The Pushback of Alleged hadith on Women Being \\ Equal to Men: Morally AND INTELLECTUALLY UNWORTHY!}

Finally, the same twin-arguments that try to deprive women of their free will also anchor the policies, laws and customs that prioritise men over women generally, treating them as unequal. Even when the so-to-speak "naturally immoral" and "intellectually deficient" arguments are implicit, as they often are, they are sown into the social psyche in some communities in an insidious manner that nonetheless enables such laws and customs to survive. Such beliefs or positions-because often they are in fact just cynical positions and not really beliefs by those who promote them-are intuitively, experientially, Qur'anically, and Prophetically unconvincing if one takes into account Muhammad's own example in this regard, which has been alluded to here and there but is not really the subject of this particular book.

Open Access This chapter is licensed under the terms of the Creative Commons Attribution 4.0 International License (http://creativecommons.org/licenses/ by $/ 4.0 /$ ), which permits use, sharing, adaptation, distribution and reproduction in any medium or format, as long as you give appropriate credit to the original author(s) and the source, provide a link to the Creative Commons licence and indicate if changes were made.

The images or other third party material in this chapter are included in the chapter's Creative Commons licence, unless indicated otherwise in a credit line to the material. If material is not included in the chapter's Creative Commons licence and your intended use is not permitted by statutory regulation or exceeds the permitted use, you will need to obtain permission directly from the copyright holder.

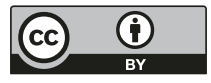

